\title{
Scientific Evaluation of Anti-obesity Potential of Methanolic Leaves extract of Ocimum sanctum (Linn.) in Monosodium Glutamate - High Fat Diet Induced Obese Mice
}

\author{
Satyajit Mohanty, Ashok Pattnaik* \\ Department of Pharmaceutical Sciences and Technology, Birla Institute of Technology, Mesra, Ranchi, Jharkhand, INDIA.
}

\begin{abstract}
Background: obesity is the deposition of body fat mass from the imbalance between calorie intake and vitality consumption. The metabolic syndrome brings the risk of health hazards like type-2diabetes, stroke and cardiovascular disease. Objectives: To evaluate the anti-obesity activity of methanolic extract of Ocimum sanctum leaves in monosodium glutamate (MSG) and high-fat diet (HFD) induced mice. Materials and Methods: To study the anti-obesity activity, free radical scavenging activity by DPPH, total phenolic content estimation, total flavonoid content and body weight were done. Group-1: Normal mice which developed in normal condition and give normal diet, Group-2: Obese mice which were given MSG-HFD (monosodium glutamate-high-fat diet), Group-3: HFD + MSG, induced obese administered with standard drug Ayurslim Tablets $120 \mathrm{mg} / \mathrm{kg} / \mathrm{day}$, for 21 days), Group-4: Obese mice treated with methanolic extract of Ocimum sanctum (Linn) $(20 \mathrm{mg} / \mathrm{kg} / \mathrm{day}$, IP as for 21 days). After the completion of the experimental period the body weight, waist-hip ratio, food intake, organ weight and adipose tissue weight were estimated in experimental groups of animals. Biochemical parameters like (AST, ALT, VLDL, HDL, triglycerides, cholesterol), as well as histological examination, were done. Results: The obtained results revealed a significant decrease in body weight, waist-hip ratio, periepididymal fat, changes in food intake, liver weight, adipose tissue weight, Biochemical parameters SGOT, SGPT, Blood glucose level, TG and LDL, VLDL when compared with an obese control group. Conclusion: Ocimum sanctum has shown significant antioxidant activity which was confirmed by in-vitro methods. There was likewise a huge diminishing in body weight, fat mass, waist circumference and organ weight (Liver), biochemical parameters which were confirmed by in-vivo evaluation of Ocimum sanctum. From the present study, the chosen herbal has the potential for antiobesity therapy.
\end{abstract}

Key words: Ocimum sanctum, Anti-obesity, MSG- HFD mice model, Methanolic extract, Body weight.

\section{INTRODUCTION}

Obesity is a chronic multifactorial disease. Obesity is defined as abnormal or excessive fat deposition present in many diseases as per the World Health Organization. Another term of obesity is the imbalance between calorie intake and energy consumption resulted in the accumulation of body fat mass. The sudden rise in obesity is due to genetic susceptibility, environmental factors like availability of high-calorie foods and a sedentary lifestyle lacking sufficient physical exercise. Obesity is a vital contributor to metabolic syndrome, a group of metabolic abnormalities including high blood sugar, extra body fats, high serum triglycerides, high blood pressure and low levels of high-density lipoproteins. The metabolic syndrome brings a high risk of severe health problems including type 2 diabetes, stroke and cardiovascular disease. ${ }^{1,2}$
Submission Date: 14-08-2020; Revision Date: 02-02-2021; Accepted Date: 03-05-2021

DOI: 10.5530/ijper.55.2s.125 Correspondence:

Dr. Ashok Pattnaik Department of Pharmaceutical Sciences and Technology, Birla Institute of Technology, Mesra, Ranchi-835215, Jharkhand, INDIA. Phone no: +91-6512276247 Email id: ashokpattnaik8@ gmail.com

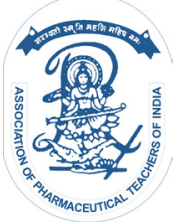

www.ijper.org 
The treatment and cure in India are based on herbal origin medicine. So a large number of plant species are used for this purpose. Among all those plants, one such plant is the Ocimum sanctum and it belongs to the family Lamiaceae. It is very much common in West Bengal, Odisha, Karnataka and Kerala. This plant is reported to have beta-sitosterol, indole alkaloids, triterpenoid and saponin, $0.7 \%$ volatile oil comprising about $20 \%$ methyl eugenol and $71 \%$ eugenol. The constituents of leaf volatile oil are eugenol, ursolic acid, caryophyllene, Linalool, limatrol, carvacrol etc. This plant helps in improving the physical, emotional and environmental stress developed in the body and mind. This plant is also used to relieve pain in the sore throat by preparing boiled water mixed with basil leaves. It is beneficial as a healing agent to bodies with chronic stress, because of its high flavonoid content. ${ }^{3,4}$

Although this plant has been used traditionally by the village people, it has not been scientifically validated so far and no scientific report is available regarding the antiobesity activity of plant leaves of Ocimum sanctum to the best of our knowledge. So, the present study was aimed to explore the anti-obesity potential of leaves of Ocimum sanctum using the MSG-HFD (monosodium glutamatehigh-fat diet) mice model.

\section{MATERIALS AND METHODS}

\section{Plant materials}

Ocimum sanctum was collected from the medicinal garden of the Birla Institute of Technology, Mesra, Ranchi, Jharkhand.

\section{Experimental Animals}

Swiss albino mice used in the experimental study were procured from Laboratory Animal House, Department of Pharmaceutical Science and Technology (Birla Institute of Technology, Mesra). The following animal experiments strictly complied with the approval of the Institutional Animal Ethical Committee (Protocol No.: 1972/PH/ $\mathrm{BIT} / 10 / 17 / \mathrm{IAEC})$. The mice were maintained under standard housing conditions (humidity $60-65 \%$ and room temperature $24-27^{\circ} \mathrm{C}$ with $12: 12$ light: dark cycles). They were accustomed for seven days before starting the study.

\section{Chemicals}

All chemicals utilized during the experiment were of analytical grade. Methanol, solvents used for the extraction were of Fisher Scientific and Rankem Company. DPPH (1, 1-diphenyl-2-picrylhydrazyl) free radical scavenging activity used was of Sigma Aldrich Company. AYUR SLIM (Himalaya), Silica gel G (Merck, Darmstadt,
Germany). Hydrogen peroxide, Ascorbic acid, Quercetin, Gallic acid, Monosodium glutamate, Glacial acetic acid, Picric acid, Hydrochloric acid, Mercuric chloride, Zinc chloride etc was used during the experiment.

\section{Preparation of Plant extract ${ }^{5,6}$}

Leaves of the plant were dried and subjected to size reduction in powder form. The powdered plant material was extracted by cold maceration using petroleumether (60-80), methanol. The extract obtained was decanted and purified by filtration, concentrated in a rotary evaporator. Methanolic leaves extract of Ocimum sanctum was showing a better presence of phytochemical and used in the following experiment. Separation and fractionation of the methanolic leaves extract were done by separating the funnel method and a compound fraction was isolated using TLC.

\section{In vitro studies}

\section{Free radical scavenging assay by $\mathrm{DPPH}^{7}$}

The sample solutions containing $1 \mathrm{ml}$ of Ocimum sanctum at $20,40,60,80,100 \mu \mathrm{g} / \mathrm{ml}$ and $1 \mathrm{ml}$ of DPPH solution $(0.1 \mathrm{ml}$, in methanol) were prepared. The stock solution of ascorbic acid at different concentrations (same as extract) was used as the reference and the solution of 1 $\mathrm{ml}$ methanol and $1 \mathrm{ml} \mathrm{DPPH}$ was taken as control. The mixtures were incubated at $37^{\circ} \mathrm{C}$ in dark for $30 \mathrm{~m}$ after shaking vigorously. The measurement of absorbance was taken at $517 \mathrm{~nm}$ against methanol as blank. The DPPH scavenging percentage was calculated as follows:

Scavenging activity $(\%)=\frac{(\text { Cortrol a bs orbance }- \text { OS a bs orbanoe) }}{\text { Control a bs orbance }} \times 100$

\section{Total Phenolic Content ${ }^{8}$}

Gallic acid was taken in concentration 10, 20, 30, 40, $50 \mu \mathrm{g} / \mathrm{ml}$ and mixed in methanol and $0.5 \mathrm{ml}$ of each sample were taken into the test tubes and mixed with $2.5 \mathrm{ml}$ of 10 -fold diluted Folin-Ciocalteu reagent and $2 \mathrm{ml}$ of $7.5 \%$ sodium carbonate. The test tubes were covered and allowed to stand for $30 \mathrm{~m}$ at room temperature before absorbance was read at $760 \mathrm{~nm}$ (UV-Visible spectrophotometer, Shimadzu). First, a standard curve of absorbance vs. concentration of Gallic acid was made and then from this curve concentration of phenolic contents of the Ocimum sanctum was measured.

\section{Total Flavonoid Content ${ }^{9}$}

The methanol crude extract was used to determine the total flavonoid content. The 5\% sodium nitrate solution was prepared by taking $(2.5 \mathrm{~g})$ sodium nitrate and mixed with water in a volumetric flask $(50 \mathrm{ml})$. The $4 \%$ sodium hydroxide solution was prepared by taking $(2.5 \mathrm{~g})$ sodium hydroxide and mixed with water in a volumetric flask 
$(50 \mathrm{ml})$. Then $10 \%$ aluminium chloride solution was preparing the same procedure. The methanolic crude extract $(0.25 \mathrm{mg})$ was taken in a test tube and added water $(1.25 \mathrm{ml})$ and sodium nitrate $(0.75 \mu \mathrm{l})$ then mixed. All the test tubes were kept in a dark place for $6 \mathrm{~m}$. Then $10 \%$ aluminium chloride $(0.150 \mu \mathrm{l})$ was added into the test tube and wait for $5 \mathrm{~m}$ in the dark for complete reaction. Finally, $5 \%$ sodium hydroxide $(0.5 \mathrm{ml})$ and water $(0.275 \mathrm{ml})$ were added to the test tube. The measurement of absorbance of all samples was taken at a fixed wavelength of $510 \mathrm{~nm}$ using a (UV-Visible spectrophotometer, Shimadzu). The estimation of total flavonoid contents in the crude extracts was carried out in triplicate by using the calibration curve of standard Quercetin and the results were averaged.

$$
\mathrm{X}=(\text { A. mo) } /(\text { Ao. } \mathrm{m})
$$

Where "A" is the absorption of plant crude extract solution, "X" is the flavonoid content, $\mathrm{mg} / \mathrm{g}$ plant extract, " $\mathrm{m}$ " is the weight of crude drug extract in $\mathrm{mg}$, "Ao" is the absorption of standard quercetin solution and "mo" is the weight of quercetin in the solution in $\mathrm{mg}$.

\section{In vivo studies}

\section{MSG HFD induced obesity model in mice ${ }^{10}$}

Male adult mice were mated with female mice of the same strain, in a proportion of 1:4 and were maintained in a controlled room temperature of $24-27^{\circ} \mathrm{C}$, humidity $60-65 \%$ with light darkness of $12 \mathrm{~h} \times 12 \mathrm{~h}$. Water and food were supplied as per the guideline. After delivery of pups, one subcutaneous (SC) dose of $2 \mathrm{mg} / \mathrm{g}$ MSG was given on the $2^{\text {nd }}$ and $4^{\text {th }}$ postnatal days and $4 \mathrm{mg} / \mathrm{g}$ SC MSG was given on the $6^{\text {th }}, 8^{\text {th }}$ and $10^{\text {th }}$ postnatal days, each dose dissolved in $0.01 \mathrm{ml} / \mathrm{g}$ of distilled water.

\section{HFD composition ${ }^{11}$}

A high fat diet (HFD) containing Casein $(289.0 \mathrm{~g} / \mathrm{kg})$, Lard $(310 \mathrm{~g} / \mathrm{kg})$, Butter oil $(190 \mathrm{~g} / \mathrm{kg})$, L-cystine $(3.33 \mathrm{~g} / \mathrm{kg})$, Corn oil $(16.0 \mathrm{~g} / \mathrm{kg})$, Corn starch $(207.3 \mathrm{~g} / \mathrm{kg})$, Sucrose $(90.5 \mathrm{~g} / \mathrm{kg})$, Dextrose $(115.0 \mathrm{~g} / \mathrm{kg})$, Cellulose $(50 \mathrm{~g} / \mathrm{kg})$, Vitamin mix $(13.33 \mathrm{~g} / \mathrm{kg})$, Mineral mix $(46.66 \mathrm{~g} / \mathrm{kg})$, was used to induce body weight gain in mice.

\section{Drugs and treatment}

Standard drug - Ayurslim Tablets (Himalaya)

Test drug - Ocimum sanctum

Experimental Design The mice were divided into five groups for evaluation of anti-obesity activity with each group comprising of six mice.

Group-1 (Normal control): Normal mice which developed in normal condition and give normal diet.

Group-2 (Obese control): Obese mice were selected which was developed by giving MSG-HFD diet.
Group-3 (Standard treatment): MSG-HFD induced obese administered with standard drug Ayurslim Tablets $(20 \mathrm{mg} / \mathrm{kg} / \mathrm{day}$, IP as $2 \% \mathrm{v} / \mathrm{v}$ tween solution for 21 days.).

Group-4 (Test treatment): Obese mice treated with methanolic extract of Ocimum sanctum (Linn) $(20 \mathrm{mg} / \mathrm{kg} /$ day, IP as $2 \% \mathrm{v} / \mathrm{v}$ tween solution for 21 days).

\section{Measurement of Body Weight ${ }^{12}$}

The bodyweights during the experimental periods (12 weeks) were calculated weekly and compared.

\section{Assessment of body parameters}

Food intake (g/day/mice), Weight of periepididymal fat (g), Waist circumference $(\mathrm{cm})$ were monitored periodically and changes were recorded. The food intake studies were performed daily during the entire experiment. The mice were starved $1 \mathrm{~h}$ before the assessment and the test feed (HFD) were given. During experimental periods, $30 \mathrm{~m}$ after drug administration, $10 \mathrm{~g}$ of HFD was offered to a group of mice in glass Petri dishes and the amount of food ingested was recorded at 0.5, 1 and $2 \mathrm{~h}$ time intervals. The bodyweight of mice $(\mathrm{g})$ was recorded each week in each study group before dosing.

\section{Changes in Liver and Adipose Tissue weight ${ }^{13}$}

The mice were euthanized by ether overdose and then different organs (liver and periepididymal fat) were removed and cleaned by keeping in $10 \% \mathrm{v} / \mathrm{v}$ formalin. Each organ was carefully weighed and preserved for histopathological examination.

\section{Determination of Biochemical Parameters ${ }^{14,15}$}

In serum, high-density lipoprotein cholesterol (HDLc), total cholesterol (TC), triglyceride (TG), aspartic transaminase (AST), alanine transaminase (ALT) and alkaline phosphatase (ALP) were determined using colorimetric kits. All parameters were determined using a UV-visible spectrophotometer.

\section{Histopathological Estimation ${ }^{16,17}$}

After anesthetizing the adipose tissues and liver were collected and fixed in neutral buffered formalin. Then it was placed in isopropyl alcohol for $2 \mathrm{~h}$ each. Then the tissue was immersed in acetone for a period of 1-2 $\mathrm{h}$ with periodical shaking. Then after adding xylene, paraffin was added and the tissue was mounted on the slides with Mayer's albumin solution and incubated in a warm oven. Slides containing paraffin sections were deparaffinized with xylene blotted. Then the tissue was rehydrated using isopropyl alcohol. Then again kept running tap water for $2 \mathrm{~m}$. Then the tissue was kept into a hematoxylin stain. The slide containing tissue was dipped into $1 \mathrm{~N} \mathrm{HCl}$ followed by Scott's water. The tissue 
was then dipped in an Eosin stain for the $30 \mathrm{~s}$. The tissue was dipped into $70 \%$ alcohol and then into $90 \%$ alcohol and pure alcohol subsequently and left for $2 \mathrm{~m}$ each. Slides were observed under a microscope with suitable magnifications (Figure 1,2).

\section{Statistical analysis}

All the data were presented as mean \pm SEM. Comparisons for the development of animal model between the normal control and MSG-HFD obese control groups were performed by students $t$-test and comparisons for anti-obesity activity between all the groups were performed by ANOVA (one-way analysis of variance) followed by Bonferroni test which includes the comparison of all pairs of the column. In all tests, the criteria for statistical significance were $p<0.05$.

\section{RESULTS}

\section{$D P P H$ radical scavenging activity}

Ocimum sanctum was showing significant DPPH free radical scavenging activity, which is comparable to standard drug ascorbic acid. Scavenging activity of Ocimum sanctum was increasing consistently with increasing concentrations (Figure 3).

\section{Total phenolic content}

Ocimum sanctum showed the presence of phenolic content which was found to be $157 \mathrm{mg} \mathrm{GAE} / \mathrm{g}$ of gallic acid equivalent.

\section{Total flavonoid content}

Ocimum sanctum showed the presence of flavonoid content which was found to be $20.50 \mathrm{mg}$ QE/g of quercetin equivalent.
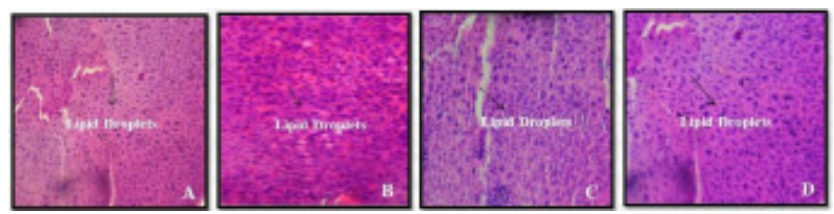

Figure 1: Histopathological Evaluation of Liver, where section-A (Normal control), Section-B (Obese control), section-C (Standard drug Ayurslim treated) and section-D (Ocimum sanctum treated).
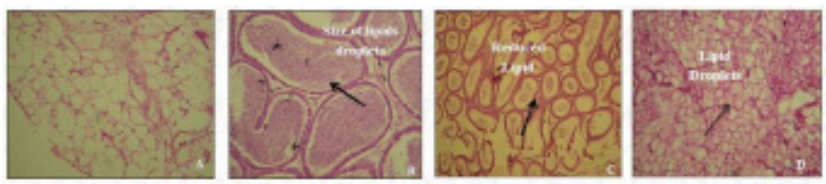

Figure 2: Histopathological Evaluation of Adipose Tissue, where section-A (Normal control), section-B (Obese control), Section-C (Standard drug Ayurslim treated) and section-D (Ocimum sanctum treated).

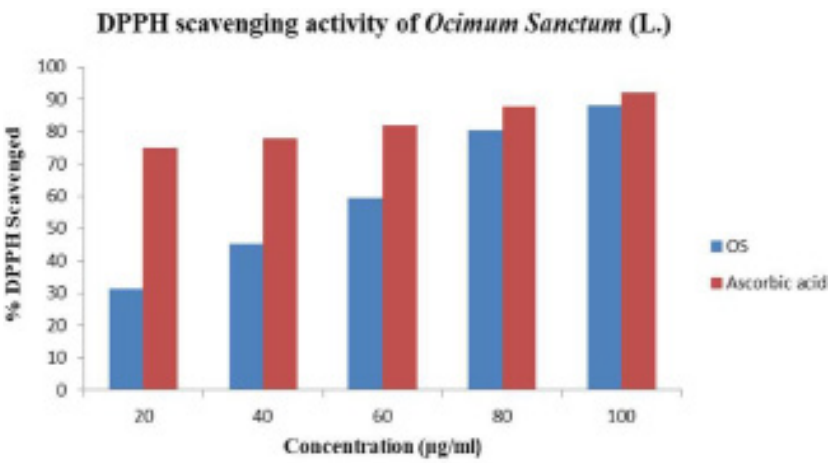

Figure 3: DPPH scavenging activity of Ocimum sanctum(L.).

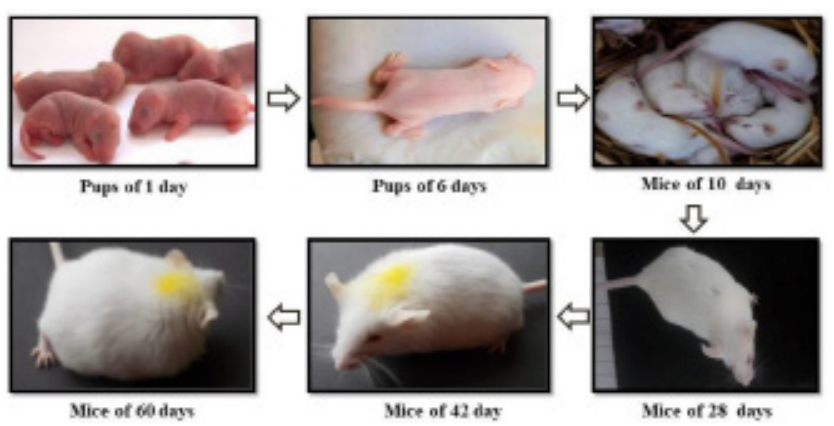

Figure 4: Development of obese mice model.

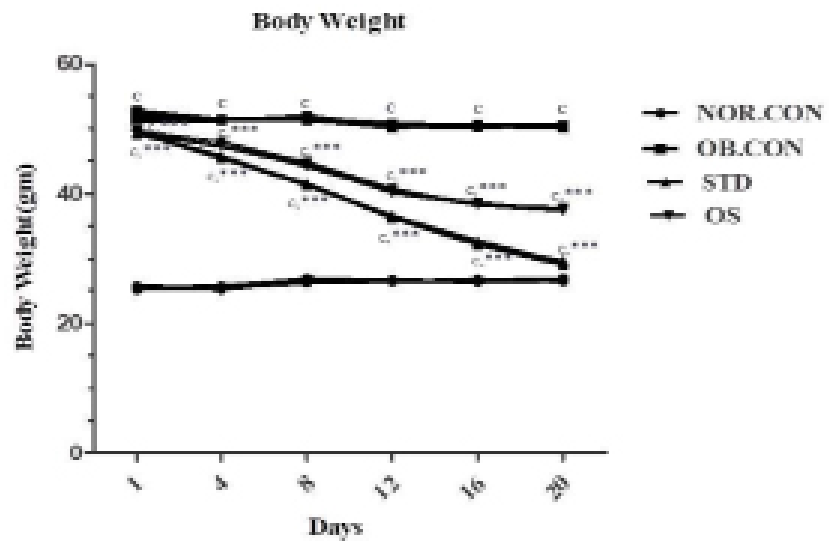

Figure 5: Changes in body Weight after drug treatment.

\section{Development of obese mice model}

Mice were developed by using a Monosodium glutamate and High-fat diet (Figure 4).

\section{Effect on body weight}

It was observed that STD, Ocimum sanctum group exhibited a highly significant reduction in body weight when compared to the obese control group where animals treated with Ayurslim have attained body weight similar to that of normal (Table 1 and Figure 5).

\section{Assessment of body parameters}

Results showed a significant reduction in food intake by Ayurslim (STD) groups when compared to the obese control group. However, a more significant reduction in 


\begin{tabular}{|c|c|c|c|c|}
\hline GROUPS & NOR. CON & OB. CON & STD & os \\
\hline Day 1 & $25.41 \pm 0.11$ & $51.81 \pm 0.27^{c}$ & $49.33 \pm 0.04^{\mathrm{c}, * * *}$ & $49.30 \pm 0.08^{\mathrm{c}, * *+}$ \\
\hline Day 4 & $25.38 \pm 0.10$ & $51.38 \pm 0.05^{c}$ & $45.65 \pm 0.09^{c, * * *}$ & $47.39 \pm 0.14^{\mathrm{c}, * *+}$ \\
\hline Day 8 & $26.51 \pm 0.17$ & $51.54 \pm 0.11^{c}$ & $41.34 \pm 0.06^{c^{* * * *}}$ & $44.55 \pm 0.14^{\mathrm{c}, *+*}$ \\
\hline Day 12 & $26.50 \pm 0.17$ & $50.45 \pm 0.09^{c}$ & $36.44 \pm 0.10^{\mathrm{c}, * * *}$ & $40.36 \pm 0.11^{c, * * *}$ \\
\hline Day 16 & $26.53 \pm 0.10$ & $50.40 \pm 0.06^{c}$ & $32.44 \pm 0.13^{c^{* * * *}}$ & $38.36 \pm 0.06^{\mathrm{c}, *+*}$ \\
\hline Day 20 & $26.61 \pm 0.11$ & $50.35 \pm 0.04^{c}$ & $29.47 \pm 0.12^{\mathrm{c}, * * *}$ & $37.51 \pm 0.08^{\mathrm{c}, * * *}$ \\
\hline
\end{tabular}

All values are expressed as means \pm S.E.M $(n=5)$. Statistically analysed using ANOVA followed by Bonferroni post hoc test where, $* p<0.05, * * p<0.01, * * * p<0.001$ denotes standard (STD) and ocimum sanctum (OS) compared with obese control (OB. CON) group; ${ }^{a} p<0.05,{ }^{b} p<0.01,{ }^{c} p<0.001$ OB.CON, (STD) and OS compared with NOR. CON) group.

\begin{tabular}{|c|c|c|c|c|}
\hline GROUPS & $\begin{array}{l}\text { NOR. } \\
\text { CON }\end{array}$ & OB. CON & STD. & os \\
\hline $\begin{array}{l}\text { Food Intake } \\
\text { (g/day/mouse) }\end{array}$ & $\begin{array}{l}4.37 \pm \\
0.05\end{array}$ & $\begin{array}{l}6.42 \pm \\
0.15^{c}\end{array}$ & $\begin{array}{l}4.38 \pm \\
0.12^{\mathrm{b}, *}\end{array}$ & $\begin{array}{l}4.58 \pm \\
0.12^{\mathrm{b}, *}\end{array}$ \\
\hline $\begin{array}{c}\text { Waist } \\
\text { circumference } \\
(\mathrm{cm})\end{array}$ & $\begin{array}{c}8.13 \pm \\
0.05\end{array}$ & $\begin{array}{c}13.46 \pm \\
0.06^{c}\end{array}$ & $\begin{array}{l}9.31 \pm \\
0.06^{c, \ldots+*}\end{array}$ & $\begin{array}{l}10.48 \pm \\
0.12^{c, * * *}\end{array}$ \\
\hline $\begin{array}{l}\text { Weight of } \\
\text { periepididymal } \\
\text { fat(g) }\end{array}$ & $\begin{array}{c}0.38 \pm \\
0.03\end{array}$ & $\begin{array}{l}3.37 \pm \\
0.13^{c}\end{array}$ & $\begin{array}{l}1.60 \pm \\
0.11^{c, t+*}\end{array}$ & $\begin{array}{r}2.28 \\
\pm 0.07^{\mathrm{c}}\end{array}$ \\
\hline
\end{tabular}

All values are expressed as means \pm S.E.M $(n=5)$. Statistically analysed using ANOVA followed by Bonferroni post hoc test whęre, ${ }^{*} p<0.05, * * p<0.01, * * * p<0.001$ STD and OS compared with OB. CON group; $p<0.05, p<0.01, p<0.001$ OB.CON, STD and OS)compared with normal control (NOR. CON) group.

the Ocimum sanctum group was observed than the obese control group and it also showed similar food intake as that of the normal control group during the treatment period. In the case of waist circumference a significant decrease in by STD and Ocimum sanctum group when compared to theobese controlgroup. Waistcircumference is the major body parameter for the measurement of central obesity. Similarly periepididymal fat of the treatment group with STD and Ocimum sanctum showed a highly significant reduction compared to the obese control group (Table 2, Figures 6-8).

\section{Changes In liver and adipose tissue weight}

Liver weight was increased significantly in the obese group as compared to the normal group which may be due to the presence of hepatocytes. But in the STD group, the Ocimum sanctum group, the liver weight was significantly decreased. Adipose tissue weight was significantly decreased in the STD group, Ocimum sanctum group compared to the obese control group (Table 3, Figure 9 and Figure 10).

\section{Assessment of biochemical parameters}

There was a highly significant $(p<0.001)$ decrease in the AST level in the STD group treated with Ayurslim,

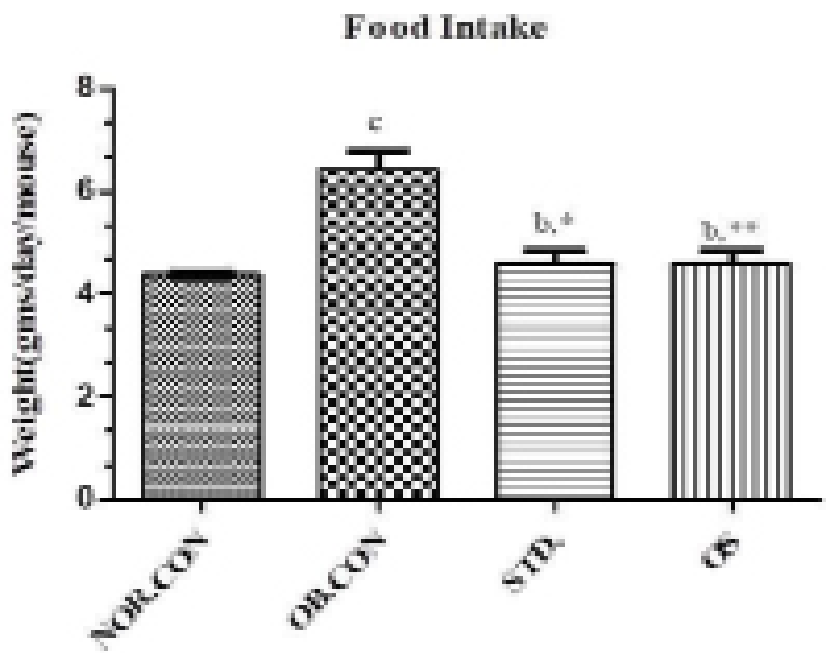

Figure 6: Changes in food intake among different groups.

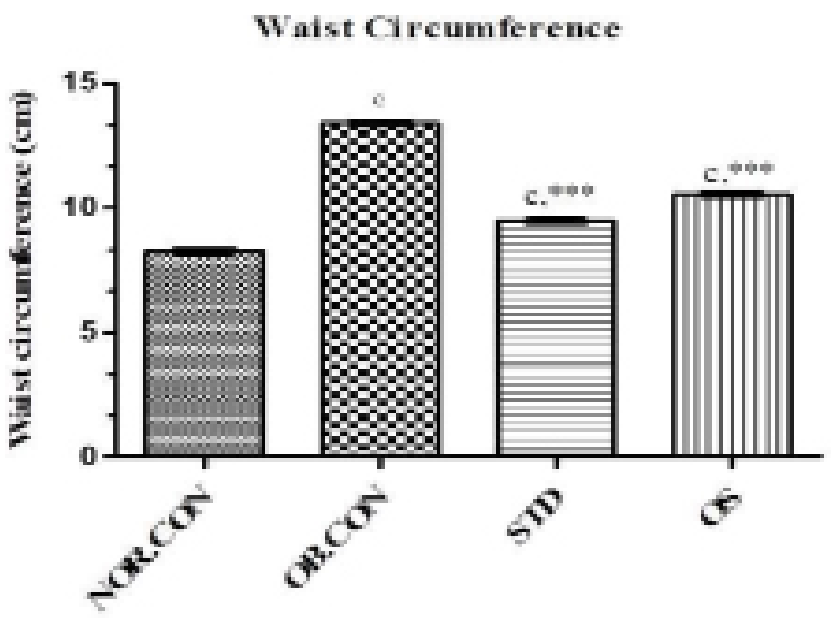

Figure 7: Changes in waist circumference among different groups.

Ocimum sanctum group treated with Ocimum sanctum than the obese control group and there was a significant decrease $(p<0.05)$ compared to the obese group. There was a significant decrease $(p<0.01),(p<0.05)$ in the ALT level in the STD group (Ayurslim) and the Ocimum sanctum group than the obese control group. But the ALT level has comparatively decreased more in the 


\section{Pertepididymal Fat}

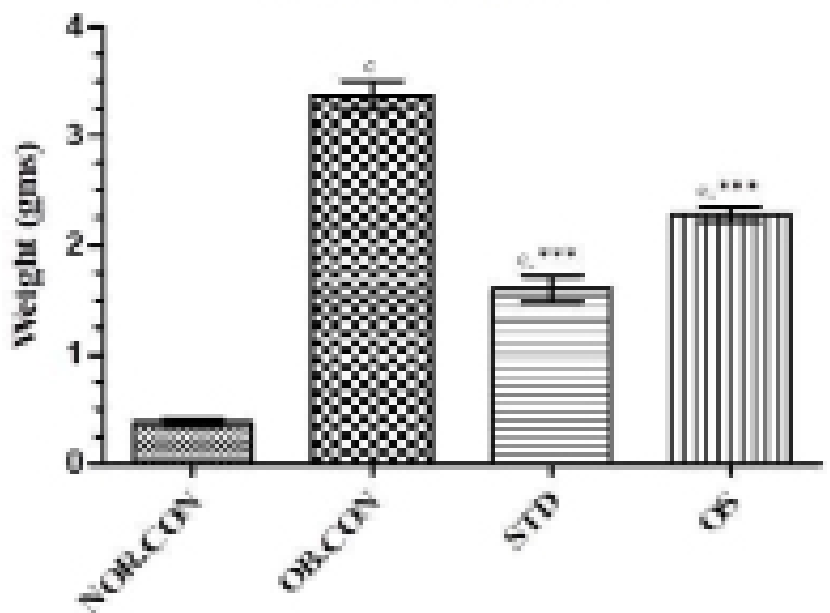

Figure 8: Changes in fat mass among different groups.

\begin{tabular}{|c|c|c|c|c|}
\hline $\begin{array}{l}\text { Parameters } \\
\text { Measured }\end{array}$ & $\begin{array}{l}\text { NOR. } \\
\text { CON }\end{array}$ & $\begin{array}{l}\text { OB. } \\
\text { CON }\end{array}$ & STD & os \\
\hline Liver Weight(g) & $\begin{array}{l}1.30 \pm \\
0.02\end{array}$ & $\begin{array}{l}1.42 \pm \\
0.01^{c}\end{array}$ & $\begin{array}{l}1.34 \pm \\
0.09^{\mathrm{a},+*}\end{array}$ & $\begin{array}{l}1.37 \pm \\
0.02^{\mathrm{c}, * * *}\end{array}$ \\
\hline $\begin{array}{c}\text { Adipose Tissue } \\
\text { Weight (g) }\end{array}$ & $\begin{array}{c}0.70 \pm \\
0.01\end{array}$ & $\begin{array}{l}1.71 \pm \\
0.04^{\mathrm{c}}\end{array}$ & $\begin{array}{l}1.51 \pm \\
0.03^{\mathrm{c},+*+}\end{array}$ & $\begin{array}{c}68 \pm \\
0.03^{\mathrm{c}, * *+}\end{array}$ \\
\hline
\end{tabular}

All values are expressed as means \pm S.E.M $(n=5)$. Statistically analysed using ANOVA followed by Bonferroni post hoc test where, ${ }^{*} p<0.05, * * p<_{\mathrm{a}} 0.01, * * * p<0.001$ STD and OS compared with obese control (OB. CON) group; $p<0.05, p<0.01$, $p<0.001$ OB.CON, STD and OS compared with normal control (NOR. CON) group.

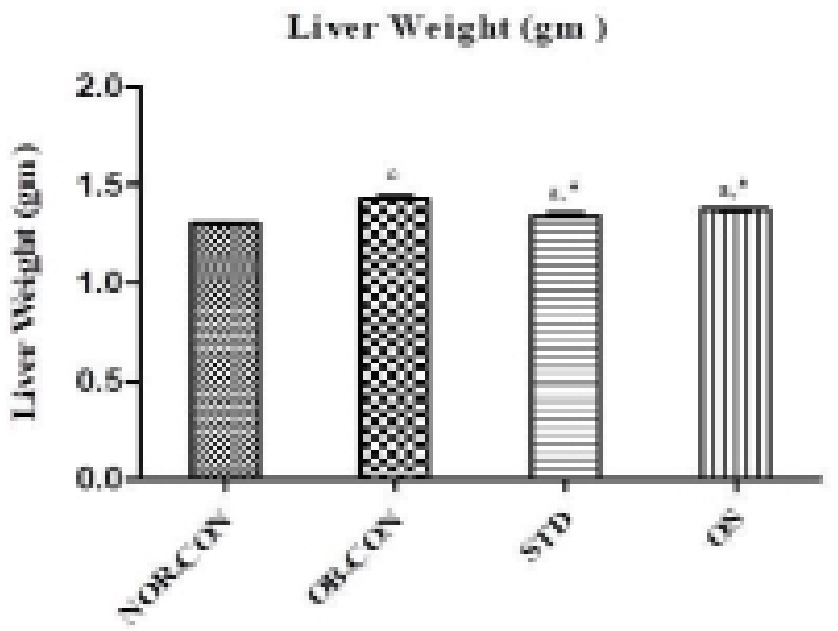

Figure 9: Changes in liver weight.

standard treatment group than the Ocimum sanctum group. There was a significant increase in blood glucose levels in the obese control group which may be due to adipose tissue deposition; probably the deposition is due to damage in the arcuate nucleus by monosodium glutamate and high-fat diet. There was a highly significant decrease $(p<0.001)$ in blood glucose levels when treated with standard drug i.e., Ayurslim, test drug i.e.,

\section{Adipose Tisue Weight (gm)}

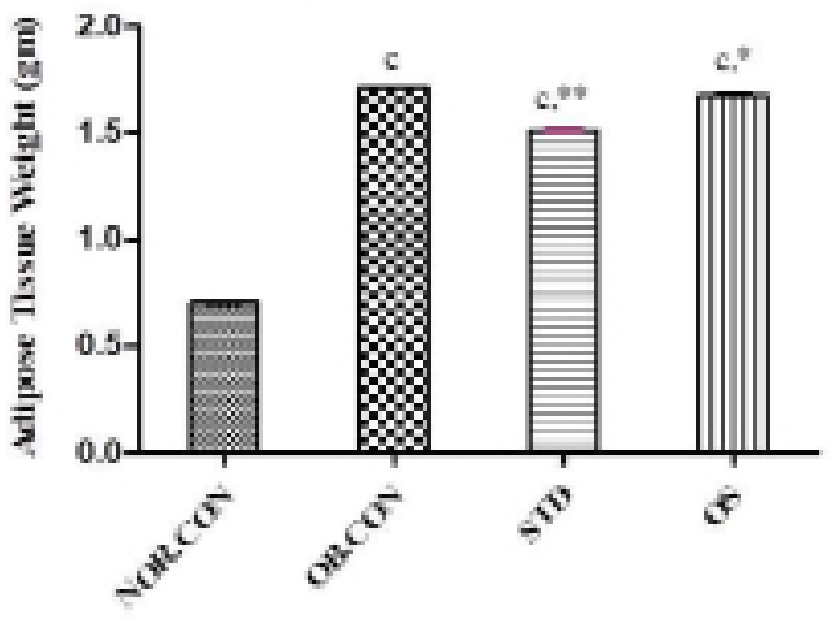

Figure 10: Changes in adipose tissue weight.

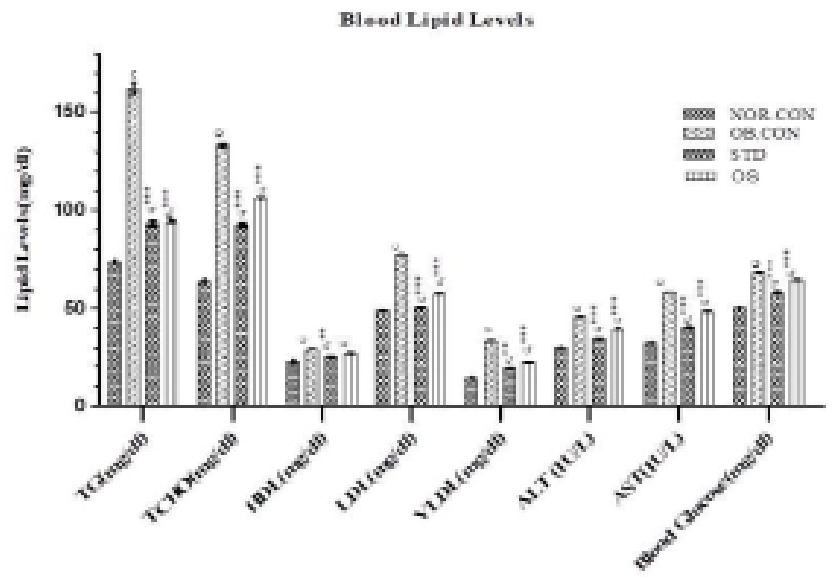

Figure 11: Changes in lipid levels among different groups.

Ocimum sanctum when compared to the obese group. There was a highly significant $(p<0.001)$ decrease in the total cholesterol level and LDL in the STD group and Ocimum sanctum group when compared with the obese control group. There was no significant difference in the HDL level in the STD group and Ocimum sanctum group compared to an obese control group. There was a significant decrease $(p<0.05)$ in VLDL in the standard group compared to the obese control group but no significant difference among the treatment group (Table 4 and Figure 11).

\section{Effect on Histopathology of liver and adipose tissues Histopathological evaluation of liver}

It is a qualitative observational study, where NOR.CON group Section-A (There was no deposition of lipid droplets observed), where OB.CON Section-B (There was more amount lipid droplet observed) and STD. group treated section-C (There was absence deposition of lipid droplet observed) but in Ocimum sanctum group 


\begin{tabular}{|c|c|c|c|c|}
\hline GROUPS & $\begin{array}{l}\text { NOR. } \\
\text { CON }\end{array}$ & OB. CON & STD. & os \\
\hline $\mathrm{TCHO}(\mathrm{mg} / \mathrm{dl})$ & $\begin{array}{c}62 \\
\pm 1.32\end{array}$ & $\begin{array}{c}132 \\
\pm 1.00^{c}\end{array}$ & $\begin{array}{c}94 \pm \\
1.07^{\mathrm{c},+* *}\end{array}$ & $\begin{array}{l}105 \pm \\
0.70^{\mathrm{c}, * *}\end{array}$ \\
\hline $\mathrm{HDL}(\mathrm{mg} / \mathrm{dl})$ & $\begin{array}{l}21 \pm \\
1.07\end{array}$ & $\begin{array}{c}29.17 \pm \\
0.08^{c}\end{array}$ & $\begin{array}{l}25.17 \pm \\
0.06^{a, * *}\end{array}$ & $\begin{array}{c}27.76 \pm \\
0.44^{c}\end{array}$ \\
\hline LDL(mg/dl) & $\begin{array}{c}49.22 \pm \\
0.11\end{array}$ & $\begin{array}{c}29.17 \pm \\
0.08^{c}\end{array}$ & $\begin{array}{c}50 \pm \\
0.07^{\mathrm{c}}\end{array}$ & $\begin{array}{l}57.4 \pm \\
0.44^{c}\end{array}$ \\
\hline $\operatorname{VLDL}(\mathrm{mg} / \mathrm{dl})$ & $\begin{array}{c}14.36 \pm \\
0.17\end{array}$ & $\begin{array}{c}77.44^{ \pm} \\
0.14^{\mathrm{c}}\end{array}$ & $\begin{array}{l}19.27 \pm \\
0.11^{c, * * *}\end{array}$ & $\begin{array}{l}22.21 \pm \\
0.08^{c}\end{array}$ \\
\hline ALT(IU/L) & $\begin{array}{c}30.27 \pm \\
0.12\end{array}$ & $\begin{array}{c}33.25 \pm \\
0.10^{c}\end{array}$ & $\begin{array}{l}34.27 \pm \\
0.12^{\mathrm{c}, * \pm *}\end{array}$ & $\begin{array}{l}39.25 \pm \\
0.11^{\mathrm{c}, *+*}\end{array}$ \\
\hline AST(IU/L) & $\begin{array}{c}32.28 \pm \\
0.14\end{array}$ & $\begin{array}{c}45.47 \pm \\
0.19^{c}\end{array}$ & $\begin{array}{l}40.27 \pm \\
0.07^{c, * *}\end{array}$ & $\begin{array}{l}48.33 \pm \\
0.11^{c, * *}\end{array}$ \\
\hline $\mathrm{TG}(\mathrm{mg} / \mathrm{dl})$ & $\begin{array}{c}70 \\
\pm 1.03 \\
\end{array}$ & $\begin{array}{c}165 \\
\pm 2.83^{\circ} \\
\end{array}$ & $\begin{array}{c}95 \pm \\
1.30^{\mathrm{c}, * * *}\end{array}$ & $\begin{array}{c}98 \pm \\
1.20^{\mathrm{c}, * * *}\end{array}$ \\
\hline $\begin{array}{c}\text { Blood } \\
\text { Glucose(mg/dl) }\end{array}$ & $\begin{array}{l}50.19 \\
\pm 0.15\end{array}$ & $\begin{array}{c}68.15 \pm \\
0.06^{c}\end{array}$ & $\begin{array}{l}58.27 \pm \\
0.08^{c, * * *}\end{array}$ & $\begin{array}{l}64.19 \pm \\
0.07^{c, * * *}\end{array}$ \\
\hline
\end{tabular}

All values are expressed as means \pm S.E.M $(n=5)$. Statistically analysed using ANOVA followed by Bonferroni post hoc test where, $* p<0.05, * * p<0.01, * * * p<0.001$ STD and OS compared with OB. CON group; $p<0.05, p<0.01, p<0.001$ OB.CON, STD and OS compared with NOR. CON group.

treated section-D liver showed the fewer number of lipid droplets. Histopathological evaluation is regarded as the gold standard indicates to evaluate the presence of lipid droplets deposition in hepatocytes leading to damage in the liver. Thus liver sections were evaluated histologically to assess the extent to which test drugs and standard attenuated the development of hepatic steatosis (Figure 1).

\section{Histopathological evaluation of adipose tissue}

Examination of adipose tissue i.e. NOR.CON group section-A (There was no-showed prominent development of lipid droplets observed), where OB.CON Section-B (There was an increase in the size of lipid droplets observed) and STD. group treated section-C (There was a reduction in the size of the lipid droplets observed). But in the Ocimum sanctum group treated section-D (showed reduced lipid droplets but the reductions of size were less than the standard treatment. In the adipose tissues of obese control, there was the prominent observation of large adipocytes which was reduced in the standard treatment group. There was a decrease in the size of adipocytes in the Ocimum sanctum test treatment group but a marked reduction of adipocytes like the standard treatment group was observed (Figure 2).

\section{DISCUSSION}

Several formulations of plants used in herbal medicine to cut down obesity could be utilized to reduce the side effects of the current allopathic anti-obesity agents. The present study aims to investigate the anti-obesity activity of Indian medicinal plants i.e. Ocimum sanctum leaves. The anti-obesity activity of plants investigated using Monosodium glutamate $4 \mathrm{mg} / \mathrm{g}$ dose SC and High-fat diet induced obesity in mice, measured parameters in obesity-induced animals are food intake, body weight and tissue weight, triglyceride, total cholesterol. There were no toxic effects observed when the normal healthy mice were administered with the extracts $(20 \mathrm{mg} / \mathrm{kg} / \mathrm{day}$ in IP). Treatment with plant extracts shows a decrease in elevated lipid, glucose levels, epididymal fat mass and body weight in MSG-HFD induced obese mice. The most widely studied mechanisms in obesity are pancreatic lipase inhibition used to determine the potential efficiency of natural products as an anti-obesity drug. ${ }^{18}$ There have been many reports on the anti-obesity activity of some medicinal plants like Orthosiphon aristatus, Perilla frutescens, Rosmarinus officinalis leaves and Nepeta tenuifolia Benth of the same Lamiaceae family and further, some reports revealed about phytoconstituents such as betasitosterol, stigmasterol, ursolic acid, quercetin, carnosic acid and their molecular mechanistic study with the antiobesity property. ${ }^{19,20}$ Thus, this study also postulates that phenols and flavonoids present in the methanolic extract of Ocimum sanctum resulted in the reduction of food intake in experimental groups. From the phytochemical study report, it was found that the Ocimum sanctum is enriched with myricetin, beta-sitosterol, quercetin, esterase, tannins, ellagic acid, quercetin, rutin, saponins and Vitamins. ${ }^{21,22}$ The histological sections of liver and adipose tissue were observed for different animal groups. There was a significant decrease in hepatic steatosis in liver sections of animals treated with Ayurslim when compared to the test compound. The anti-obesity activities of the methanolic leaf extract of Ocimum sanctum might be due to the action of phytoconstituents present in them. These results claim that Ocimum sanctum is a potential herbal drug that is effective against fat accumulation, weight gain, maintaining blood glucose and correcting lipid levels.

\section{CONCLUSION}

This experimental work strongly indicated their great potential as an anti-obesity activity. The mice model designed for conducting the study was developed by subcutaneous administration of monosodium glutamate in neonatal pups was further continued by feeding high-fat diet to facilitate obesity. Intraperitoneal administration of $20 \mathrm{mg} / \mathrm{kg}$ of extracts reduced the level of lipid droplets as well as the amount of adipose tissues, resulting in the remarkable improvement in 
the obese animal model bearing a close resemblance to human obesity. Extracts enriched with flavonoids, tannins, saponins and phenols appeared to exhibit a range of activities by modulating the lipid metabolism mediated by the inhibition of pancreatic amylase activity and decreased activity in lipogenesis, as well as an increase in fatty acid oxidation. Ocimum sanctum (Linn.) has shown more promising effects compared to Ayurslim. Histopathological examination claimed that Ocimum sanctum significantly reduced the accumulation of fatty acid in the liver and showed improved effects in reducing adipocyte hypertrophy. Therefore, this study established that Ocimum sanctum extract had a beneficial effect in the management of obesity.

\section{ACKNOWLEDGEMENT}

The authors are thankful to the Head, Department of Pharmaceutical Sciences and Technology, BIT Mesra, Ranchi for providing the required facilities for carrying out this project.

\section{CONFLICT OF INTEREST}

The authors declare no conflict of interest.

\section{ABBREVIATIONS}

DPPH: Diphenylpicrylhydrazyl,OS-Ocimumsanctum; STD: Standard; NOR.CON: Normal control; OB.CON: Obese control; SEM: Standard error Mean; ANOVA: Analysis of Variance; MSG: Monosodium glutamate; HFD: High fat diet; SC: Subcutaneous.

\section{REFERENCES}

1. Narayanaswami V, Dwoskin LP. Obesity: Current and potential pharmacotherapeutics and targets. Pharmacology and Therapeutics. 2017;170:116-47.

2. Bano N, Ahmed A, Tanveer M, Khan GM, Ansari MT. Pharmacological Evaluation of Ocimum sanctum. Journal of Bioequivalence Available. 2017;9(3):387-492.

3. Prakash P, Gupta N. Therapeutic uses of Ocimum sanctum Linn (Tulsi) with a note on eugenol and its pharmacological actions: A short review. Indian Journal of Physiology and Pharmacology. 2005;49(2):125.

4. Sun NN, Wu TY, Chau CF. Natural dietary and herbal products in anti-obesity treatment. Molecules. 2016;21(10):1351.
5. Vetal MD, Lade VG, Rathod VK. Extraction of ursolic acid from Ocimum sanctum leaves: Kinetics and modelling. Food and Bio products processing. 2012;90(4):793-8.

6. Harborne JB. Phytochemical Methods: A guide to modern techniques of plant analysis. Springer science and business media. $3^{\text {rd }}$ ed. 1988;4-96.

7. Royera M, Dioufb PN, Stevanovic T. Polyphenol contents and radical scavenging capacities of red maple Acer rubrum L. extracts. Food Chem Toxicol. 2011;49(9):2180-8.

8. Baba SA, Malik SA. Determination of total phenolic and flavonoid content, antimicrobial and antioxidant activity of a root extract of Arisaema jacquemontii Blume. Journal of Taibah University for Science. 2015;9(4):449-54.

9. Do QD, Angkawijaya AE, Tran-Nguyen PL, Huynh LH, Soetaredjo FE, et al. Effect of extraction solvent on total phenol content, total flavonoid content and antioxidant activity of Limnophila aromatica. Journal of Food and Drug Analysis. 2014;2(3):296-30.

10. Alarcon-Aguilar FJ, Zamilpa A, Perez-Garcia MD, Almanza-Perez JC, Romero-Nunez E, Campos-Sepulveda EA, et al. R. Effect of Hibiscus sabdariffa on obesity in MSG mice. Journal of Ethnopharmacology. 2007;114(1):66-71.

11. Flegal KM, Carroll MD, Ogden CL, Johnson CL. Prevalence and trends in obesity among US adults, 1999-2000. The Journal of the American Medical Association. 2002;288(14):1723-7.

12. Bhargava SK, Sachdev HS, Fall CH, Osmond C, Lakshmy R, Barker DJ, et al. Relation of serial changes in childhood body-mass index to impaired glucose tolerance in young adulthood. New England Journal of Medicine. 2004;350(9):865-75.

13. Kaur G, Kulkarni SK. Differential effect of polyherbal, anti-obesity preparation, OB-200G in male and female mice and monosodium glutamate-treated rats. The Journal of the American Medical Association. 2016;115(5):44-12.

14. Wang Y, Si S, Liu J, Wang Z, Jia H, Feng K, et al. The associations of serum lipids with Vitamin D status. Public Library of Science. 2016;11(10):0165157.

15. Reitman S, Frankel S. A colorimetric method for the determination of serum glutamic oxalacetic and glutamic pyruvic transaminases. American Journal of Clinical Pathology. 1957;28(1):56-63.

16. Pattanayak SP, Sunita P, Mazumder PM. Restorative effect of Dendrophthoe falcata (Lf) Ettingsh on lipids, lipoproteins and lipid-metabolizing enzymes in DMBA induced mammary gland carcinogenesis in Wistar female rats. Comparative Clinical Pathology. 2014;23(4):1013-22.

17. Bang RL, Dashti H. Keloid hypertrophic scars: Trace element alteration. J Nutrition. 1995;11(5 Suppl):527.

18. Kim GN, Shin MR, Shin SH, Lee AR, Lee JY, Seo BI, et al. Study of antiobesity effect through inhibition of pancreatic lipase activity of Diospyros kaki fruit and Citrus unshiu peel. Bio Med Research International. 2016;7.

19. Patra S, Nithya S, Srinithya B, Meenakshi SM. Review of medicinal plants for anti-obesity activity. Translational Biomedicine. 2015;6(3):1-23.

20. Karri S, Sharma S, Hatware K, Patil K. Natural anti-obesity agents and their therapeutic role in management of obesity: A future trend perspective. Biomedicine and Pharmacotherapy. 2019;110:224-38.

21. Kumar A, Shukla R, Singh P, Dubey NK. Chemical composition, antifungal and antiaflatoxigenic activities of Ocimum sanctum $L$. essential oil and its safety assessment as plant based antimicrobial. Food and Chemical Toxicology. 2010;48(2):539-43.

22. Gupta P, Yadav DK, Siripurapu KB, Palit G, Maurya R. Constituents of Ocimum sanctum with antistress activity. Journal of Natural Products. 2007;70(9):1410-6. 
PICTORIAL ABSTRACT

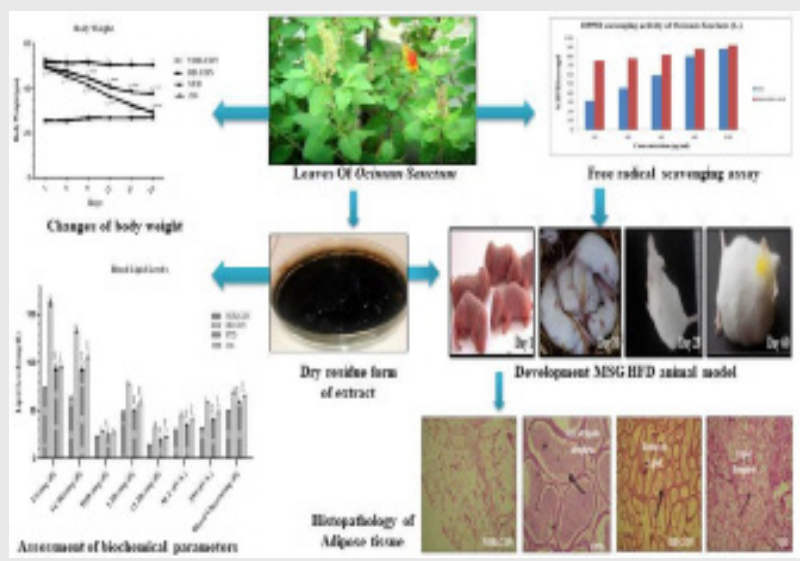

About Authors

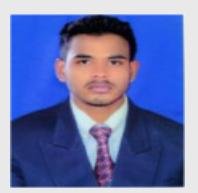

Mr. Satyajit Mohanty, did his M.Pharm under the supervision of A.K Pattnaik from the Department of Pharmaceutical Sciences and Technology, BIT Mesra, Ranchi. Currently, he is doing $\mathrm{PhD}$ from the Department of Pharmaceutical Sciences and Technology, BIT Mesra, Ranchi. He is actively involved in the following research fields: (Obesity, Wound healing, CNS study).

Dr. Ashok Pattnaik, did his Ph.D from Department of Pharmaceutical Sciences and Technology, Birla Institute of Technology, Mesra, Ranchi. Currently, he is working as an Associate Professor at the Department of Pharmaceutical Science and Technology, BIT Mesra. The major focus of Dr. Ashok Pattnaik is on understanding the molecular mechanism and target pathway of obesity and wound healing activity and to explore Anti-obesity activity of various synthetic and Medicinal Plants in different animal model. He has more than 22 nos research publication in his research credential.

Cite this article: Mohanty S, Pattnaik A. Scientific Evaluation of Anti-obesity Potential of Methanolic Leaves extract of Ocimum Sanctum (Linn.) in Monosodium Glutamate - High Fat Diet Induced Obese Mice. Indian J of Pharmaceutical Education and Research. 2021;55(2s):s535-s543. 